\title{
Elektron dövlət mühitində sosial münasibətlərin təhlükəsizliyi
}

\author{
Rasim Oliquliyev $^{1}$, Ramiz Alıquliyev ${ }^{2}$, İradə Oləkbərova ${ }^{3}$ \\ AMEA İnformasiya Texnologiyaları İnstitutu, Bakı, Azərbaycan \\ ${ }^{1}$ r.algulievegmail.com, ${ }^{2}$ r.aliguliyevegmail.com, 3airada.09@gmail.com
}

\begin{abstract}
Xülasə- İnformasiya texnologiyalarının vətəndaşın gündəlik həyatına və davranışına intensiv və dinamik təsiri cəmiyyətdə yeni münasibətlərin yaranmasına, ənənəvi münasibətlərdə müəyyən dəyişikliklərin baş verməsinə səbəb olmuşdur. Tədqiqatda insanlar arasında münasibətlərin xüsusiyyəti analiz olunmuş, münasibətlər forma və tipinə görə təsnifatlandırılmış, münasibətlərə təsir edən əsas faktorlar müəyyənləşdirilmişdir. E-dövlət mühitində münasibətlərin idarə olunması və təhlükəsizliyi məsələlərinin səmərəli həlli üçün təkliflər verilmişdir.
\end{abstract}

Açar sözlor- e-dövlot, informasiya tohlükasizliyi, Danbar roqəmi, aktor, münasibatlorin qiymotlondirilmosi, münasibotlorin gücü, münasibotlorin təhlükəsizliyi.

\section{GİRISS}

İnsanlar arasında münasibətlər və onların müxtəlifliyi cəmiyyətin inkişaf prosesinə, sosial-iqtisadi və siyasi vəziyyətə, dövlətin informasiya məkanının təhlükəsizliyinə təsir edən vacib faktorlardandır. Münasibətlər insanlar, təşkilatlar, partiyalar, şirkətlər və ölkələr arasında olur. Cəmiyyətdəki münasibətlərin xarakterini tədqiq edən bir sira elmi istiqamətlər vardır. $\mathrm{Bu}$ istiqamətlərə sosiologiya, psixologiya, informasiya texnologiyaları, antropologiya, hüquq, iqtisadiyyat və s. daxildir [1]. Məsələn, biznesin inkişafında münasibətlərin analizi metodlarından istifadə etmək artıq ənənə halını almışdır.

Sosial münasibətlər dedikdə sosial qruplar və ya onların üzvləri arasında sənaye, iqtisadi, hüquqi, əxlaqi, siyasi, dini, etnik və digər sahələrdə baş verən proseslərdə yaranan münasibətlər nəzərdə tutulur. Münasibətləri tədqiq edən müxtəlif metod və nəzəriyyələr mövcud olsa da, bu sahədə tədqiqatlar hələ də davam etməkdədir [2].

Tədqiqatın məqsədi e-dövlətdə münasibətlərin xüsusiyyətinə aydınlıq gətirmək, onları ayrı-ayrı əlamətlərə görə təsnifatlandırmaqla idarə olunması və təhlükəsizlik məsələlərinin həlli üçün təkliflərin işlənməsidir.

\section{MÜNASİBӘTLӘTIN AVTOMATİK ANALIZİ SISTEMLӘRİ}

Cəmiyyətdəki münasibətlərini analiz edən və aşkarlayan müxtəlif sistemlər mövcuddur [3-5]. Bu sistemlər müəyyən təşkilat daxilində, sosial şəbəkədə və ya dünyada insanlar arasında münasibətləri analiz etmək üçün nəzərdə tutulmuşdur.
İnternet məkanında münasibətlərin analizi üçün sistemlər təklif olunur. Bu sistemlərdən biri də 2010-cu ildən ABŞ-1n NyuYork şəhərində "RelSci" şirkəti tərəfindən təklif olunan "Relationship Science" sistemidir [4]. Sistem dünyanın ən nüfuzlu şəxsləri haqqinda informasiya toplamaq və emal etməklə, onlar və ya onların ətrafindakılarla necə əlaqə saxlamaq haqqında bilik yaradır, münasibətlərdən istifadə etməklə daha yüksək gəlirin əldə olunması, yeni istehsal və istehlak sahələrinin əldə olunması, sazişlərin bağlanması və $\mathrm{s}$. işlərdə yardımlar təklif edir. Sistem əlaqə məlumatları və ya digər gizli fərdi məlumatların təqdimatını yerinə yetirməsə də, nüfuzlu insanlarla necə əlaqə qurmaq, bunun üçün kimlərə müraciət etmək haqqinda məlumat təqdim edir.

Münasibətlərin analizi üçün nəzərdə tutulmuş digər sistemə misal olaraq "Traxor" proqram təminatını göstərmək olar. Traxor proqramı SaaS xidmətini xatırladan proqram təminat olub, şirkət daxilində münasibətlərin idarə olunması (True Relationship Management) üçün nəzərdə tutulmuşdur. Sistem əməkdaşlar arasında münasibətlərin tipini və gücünü qiymətləndirmək üçün də istifadə oluna bilər. Sistemdə münasibətin gücü 1 və 100 arasında verilir. Məsələn, münasibətin gücü 69-dan yuxarı olarsa münasibətlər əməkdaşlıq səviyyəsində qeyd olunur. Münasibətlərin tipi xüsusi, texniki, sosial, əməkdaşlıq, qohumluq, dostluq, tanışlıq və s. ola bilər. Traxor sistemi şirkət və ya təşkilat üçün nəzərdə tutulduğundan burada yalnız xüsusi, texniki, sosial, əməkdaşlıq tipli münasibətlərin qiymətləndirilməsi yerinə yetirilir [5]:

· Xüsusi münasibətlər şirkətin işi ilə əlaqədar yaranan hər hansı problemin həlli üçün gözlənilməz müraciətlərə və ya təkliflərə aiddir.

· Texniki münasibətlər rəhbərliyin göstərişi və ya qaydalara əsasən qurulan münasibətlərdir.

- Sosial münasibətlər əməkdaşlar arasında dostluq münasibətlərinə və ya ümumi maraq sahəsinə aiddir.

· Oməkdaşlıq münasibətləri daha güclü münasibətlər hesab olunur və əməkdaşların bütün sahələrdə bir-birilərinə etimad göstərdiklərini bildirir. Hesab olunur ki, şirkətin yüksək gəlir əldə etməsi üçün əməkdaşlıq münasibətlərinin çoxalması vacibdir.

$\mathrm{Bu}$ tip sistemlərin hazırlanmasına şirkətlərin milyonlarla dollar xərcləməsi bir daha sübut edir ki, cəmiyyətdəki 
münasibətlərin qiymətləndirilməsi müasir dövrdə çox aktualdır. Osasən də biznes, maliyyə, dövlət təhlükəsizliyi, cinayətkarların aşkarlanması və s. məsələlərin həllində insanlar arasındakı münasibətlər vacib faktordur.

\section{MÜNASIBBӘTLӘRİN XÜSUSIYYЭTLӘRİ}

Münasibətləri analiz etmək üçün ilk növbədə bu sahədə tədqiqat işləri ilə tanış olmaq lazımdır. Britaniyalı antropoloq, Oksford Universitetinin professoru Robin Danbar (Robin Dunbar) tədqiqatlarında bu nəticəsyə gəlmişdir ki, hər bir insan orta hesabla 150 nəfərlə stabil (daimi) münasibətdə olur. "Danbar rəqəmi" (Dunbar numbe) adlanan bu nəzəriyyədə qeyd edilir ki, münasibətlər fərdin xarakterindəki fərqləndirici cəhətləri və sosial vəziyyətini müəyyən edir [6].

İnternet şəbəkəsinin genişləndiyi, informasiya cəmiyyətinin formalaşdığı, sosial medianın insanların həyatının bütün sahələrinə daxil olduğu müasir dövrdə "Danbar rəqəmi" nəzəriyyəsinin doğruluğu şübhyə doğurur. Lakin araşdırmalar göstərir ki, bu nəzəriyyəyə mobil əlaqələrin, sosial şəbəkələrin genişlənməsi o qədər də təsir etmir. Bu gün ən nəhəng virtual sosial şəbəkə olan Facebook-da hər bir fərdin orta hesabla 300ə yaxın "dostu" vardır. Şəbəkədəki münasibətlər istifadəçilərin yaşından asılı olaraq müxtəlifdir: 18-29 yaş arasında istifadəçilərin 27\%-nin dostlarının sayı 200-dən çox, yaş1 65 dən çox olan istifadəçilərin $72 \%$-nin dostlarının sayı isə 100dən azdir [7].

Virtual məkanda sosial medianın genişlənməsi insanların sosial münasibətlər qurmaq arzusunda olduğunu və bu münasibətləri qorumaq istədiyini sübut edir. Lakin sosial media sosial münasibətlər deyil, sosial şəbəkələr yaradır. Münasibətlər yalnız informasiya mübadiləsi aparmaqla yaranmır. Münasibətlərdə etimad, zaman, mənəvi və ya maddi təsir, nüfuz və s. faktorlar mühüm rol oynayır [8].

Cəmiyyətdəki münasibətləri qiymətləndirmək üçün ilk növbədə fərdlər arasında münasibətlərin təsnifatlandırılmasına ehtiyac vardır. Bu münasibətlər müxtəlif xüsusiyyətlərə görə fərqlənirlər. Məsələn, münasibətlər formasına görə iki qrupa bölünür:

1. Rəsmi münasibətlər. Münasibətlər nortmativ-hüquqi qaydalarla və ya hər hansı rəsmi şəxs tərəfindən qəbul olunmuş xüsusi normalar əsasında müəyyən olunur. Məsələn, xidməti münasibətlər, həmkarlar arasında əmək münasibətləri və $\mathrm{s}$.

2. Qeyri rəsmi (şəxsi) münasibətlər. Məsələn, dostluq kimi heç bir formal qaydalarla məhdudlaşdırılmayan münasibətlər qeyri-rəsmi münasibətlərə aiddir və rəsmi münasibətlərlə müqayisədə daha güclü, zəngin və etibarlıdır.

Rəsmi və qeyri rəsmi münasibətlər özləri də alt qruplara ayrilırlar: uzunmüddətli (dostlar və ya həmkarlar), q1samüddətli (təsadüfi tanışlar), daimi (ailə), təhsil müddətində, funksional (icraçı və ya sifarişçi) və subordinasiya (rəhbər və işçi) [9].

Sosial mühitdə münasibətlər təsir formasına görə fərqlənirlər və bu fərq aşağıdakı kimidir [10]:

1) Güclü münasibətlər;
2) Orta münasibətlər;

3) Zəif münasibətlər;

4) Olmayan münasibətlər.

Qohumluq münasibətlərindən başqa bütün sosial münasibətlərin başlanğıcında zəif münasibətlər dayanır və zaman keçdikcə bu münasibətlər formasını dəyişir. Məsələn, yaxın dostla münasibətlər güclü, qohumlarla orta, uzaq qohumlarla və ya tanışlarla münasibətlər isə zəif münasibətlərə aid ola bilər. Olmayan münasibətlər dedikdə, informasiya mübadiləsi aparmayan insanlar arasında münasibətlər nəzərdə tutulur. Məsələn, hər səhər küçədə qarşılaşarkən yalnız salamlaşan qonşular, avtobus sürücüsü və sərnişin, mağazadakı menecer və müştəri.

Stenford Universitetinin professoru Mark Granovetter (Mark Granovetter) apardığ1 sorğular və tədqiqatlar nəticəsində sübut etmişdir ki, zəif münasibətlər güclü münasibətlər qrupları arasında əlaqələrin yaranmasında əsas rol oynayır və körpü funksiyasını yerinə yetirirlər. Zəif münasibətlər qruplar arasında münasibətlərin güclənməsinə yardım edir. O, "Zəif əlaqələrin gücü" (The Strength of Weak Ties) nəzəriyyəsində qeyd edir ki, bütün güclü münasibətlər zəif münasibətlərdən yaranır [8]. Deməli, güclü münasibətlər cəmiyyətdə əsas olsa da, əsas sosial əlaqələr zəif münasibətlər hesabına formalaşır. Granovetter qeyd edir ki, münasibətlər üçün aşağıdakı faktorlar əsasdır:

Zaman: bir yerdə keçirilən vaxt;

İntensivlik: yaxınlıq hissi, emosiya;

Etimad: münasibətlərdə şəffaflıq, etibarlılıq;

Qarşı1ıqlı münasibət: qarş11ıqlı yardım və diqqət.

Buradan belə nəticəyə gəlmək olar ki, güclü münasibətlər daha çox zaman, diqqət və etimad tələb edir. Tədqiqatlar göstərir ki, zəif münasibətlər innovasiyaların tətbiqi, cəmiyyətdə yeni münasibətlər yaratmaq, status əldə etmək üçün əlverişlidir [9].

Zəif münasibətlər böyük sosial qrupların yaranmasında əsas faktordur. Lakin etimad, qarşılıqlı dəstək və kömək kimi xüsusiyyətlər güclü münasibətlərə aiddir. İnsanların tez-tez görüşməsi və bir-birlərinə qarşı yaranan böyük etmad güclü münasibətlərin formalaşmasına səbəb olur. Belə münasibətlər çoxluğunda informasiya daha tez yayılır və bu səbəbdən onların istifadə etdikləri informasiya təqribən eynidir. Zəif münasibətlərdə çox zaman müxtəlif və yeni məlumatlardan istifadə olunur. Yəni yeni xəbərin yayılmasında zəif münasibətlər əsas rol oynayır [11].

Cəmiyyətdə zəif münasibətlər güclü münasibətlərlə müqayisədə daha çoxdursa, belə cəmiyyətdə yeni xəbərin yayılması, cəmiyyətin idarə olunması daha sürətlə baş verəcəkdir [12].

\section{MÜNASIBBӘTLӘRİN QIYYMӘTLӘNDİRILMӘSINDӘ ӘSAS GÖSTӘRİCILӘR}

Münasibətləri qiymətləndirmək üçün ilk növbədə münasibətləri əks etdirən informasiya mənbələri müəyyən olunmalıdır və aşağıdakı faktorlar nəzərə alınmalıdır:

1) Münasibətin əhatə dairəsi - münasibətlərdə iştirak edən insanların sayı; 
2) Münasibətlərin genişlənməsi - bir fərdin münasibətdə olduğu insanların sayı;

3) Münasibətlərin dərinliyi - iki fərd arasında münasibətin gücü;

4) Münasibətlərin təsiri - bir fərdin digər fərdə və ya onun qərarına təsiri nəzərdə tutulur.

5) Münasibətlərin zamanı - münasibətlərin müəyyən zaman kəsiyində vəziyyəti.

Münasibətləri əks etdirən informasiyanı müxtəlif informasiya mənbələrindən istifadə etmək olar. Onlar aşağıdakılardır:

e-mail;

- arxivlərdə saxlanılan rəy və sənədlər;

- mobil qurğular;

- sosial media vasitələri.

Münasibətlərin modelini qurmaq üçün qraflar nəzəriyyəsindən istifadə daha məqsədəuyğundur. Belə ki, sosiologiya sahəsində nəzəri tədqiqatlar əsasında sosial strukturların və münasibətlərin vizuallaşdırılması və araşdırılması üçün qraflar nəzəriyyəsinin riyazi əsaslarından istifadə etməklə unikal metodologiyalar geniş istifadə olunmaqdadir [13].

Qraflar nəzəriyyəsinə görə, cəmiyyətin modeli $C=(H, R)$ ilə verilə bilər. $H$ - fərdlər çoxluğu, $R$ isə münasibətlər çoxluğudur:

$$
\begin{gathered}
H=\left\{h_{1}, h_{2}, \ldots h_{i}\right\} \\
R=\left\{r_{1}, r_{2}, \ldots r_{i}\right\}
\end{gathered}
$$

$R_{0} \quad$ - rəsmi münasibətlər çoxluğu, $R_{u}$ isə qeyri-rəsmi münasibətlər çoxluğursa, olacaqdır:

$$
\begin{aligned}
& R_{0}=R_{0}^{s} \cup R_{0}^{d} \\
& R_{u}=R_{u}^{s} \cup R_{u}^{d}
\end{aligned}
$$

burada, $R_{0}^{s}$-statik rəsmi münasibətlər,

$R_{0}^{d}$-dinamik rəsmi münasibətlər,

$R_{u}^{s}$ - statik qeyri-rəsmi münasibətlər,

$R_{u}^{d}$-dinamik qeyri-rəsmi münasibətlərdir.

Münasibətlər gizli və aşkar, həmçinin birtərəfli və ikitərəfli (qarş11ıl1) olurlar. Məsələn, müəllim və şagird, zabit və əsgər, rəhbər və işçi arasında birtərəfli münsibətlər mövcuddur, tələbələr və ya əsgərlər arasında isə ikitərəfli münasibətlər mövcuddur. Tutaq ki, iki aktor arasında birtərəfli münasibətlər vardır, onda $H_{i} \rightarrow H_{j}$ ilə içarə olunur. Ogər münasibətlər qarşılıqlıdırsa, onda $H_{j} \leftrightarrow H_{k}$ ilə işarə olunur (şəkil 1).

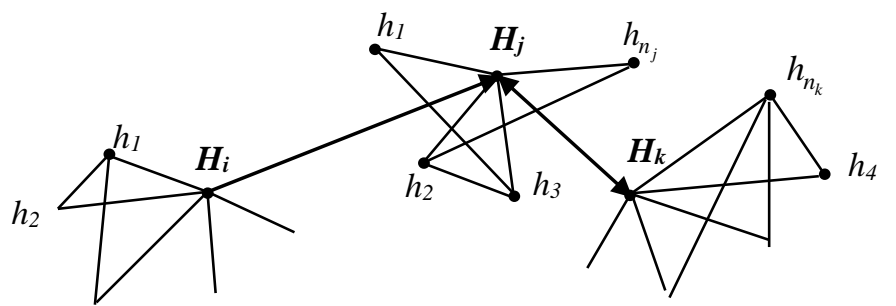

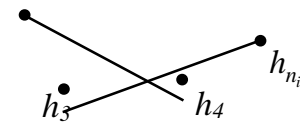

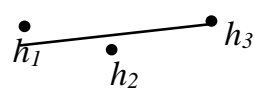

Şəkil 1. Münasibətlər qrafı

Bir çox hallarda münasibətlərdə müəyyən aktorlar lider olurlar və digər aktorlar liderin ətrafinda toplanır. Məsələn, universitetin professorları ilə tələbələr, təșkiların rəhbərliyi və əməkdaşlar arasında münasibətlər və s. Şəkildən göründüyü kimi $H_{i}, H_{j}$ və $H_{k}$ qovşaqları liderlərdir və güclü münasibətlərlə bağlı olan qraflar arasında əlaqələrin yaranmasında əsas rol oynayırlar.

Cəmiyyətdə münasibətləri analiz etmək üçün verilənlərin intellektual anlizi, "text mining", kontent-analiz, LIWC (linguistic inquiry and word count), ICA (independent component analysis), tematik modelləşdirmə və s. metodlar mövcuddur. Məsələn, ICA metodundan istifadə etməklə təsadüfi qiymətlər çoxluğundan gizli faktorları (münasibətləri) müəyyən etmək mümkündür [14].

\section{MÜNASIBӘTLӘRIN TəHLÜKӘSIZLIYİ VӘ IDARӘ OLUNMASI}

E-dövlətin təhlükəsizliyi, vətəndaşların sosial və iqtisadi həyatda rifahı, psixoloji durumu münasibətlərdən çox asılı olduğu üçün münasibətlərin idarə olunması və təhlükəsizliyinin təmini e-dövlət mühitində vacib məsələlərdəndir. Məsələn, ailədə münasibətlərin pozulması ailə dəyərlərinin məhvinə, uşaqlar arasında cinayətkarlığa, ailə üzvlərinin sosial və maliyyə durumunun pisləşməsinə səbəb ola bilər.

Münasibətlərin təhlükəsizliyi dedikdə münasibətlərin qorunub saxlanması nəzərdə tutulur. Biznes, təhsil və $\mathrm{s}$. sahələrdə münasibətlərin qorunmasına, həmçinin gücləndirilməsinə ehtiyac vardır. Məsələn, şirkət daxilində rəhbərliklə işçilər arasında münasibətlər pozularsa bu işin keyfiyyətinin aşağı düşməsinə və ən pis halda dəyərli işçilərin şirkətdən getməsinə səbəb ola bilər. Təcrübəli işçilərin yeni işçilərlə əvəz olunması isə şirkətin gəlirinin azalmasına səbəb olacaqdir.

Münasibətlərin təhlükəsizliyinin təmini üçün onların düzgün qurulması yetərli deyil, həm də münasibətlərin düzgün idarə olunması vacibdir. Münasibətlərin təhlükəsizliyi üçün aşağıdakı bir sıra faktorlar nəzərə alınmalıdır:

- Münasibətdə olan insanların say1;

Güclü münasibətlərin və əməkdaşlığın səbəbləri;

Konfliktlərin say1 və səbəbləri;

- Zəif münasibətlərin say1;

Münasibətin sosial-iqtisadi duruma təsiri.

Münasibətlərin təhlükəsizliyinə vətəndaşın sosial-iqtisadi vəziyyətinin pisləşməsində əvvəlcədən xəbərdarlıq sistemi kimi də baxmaq olar. Münasibətlərin təhlükəsizliyi sosial kapitalın artmasında və yeni imkanların yaranmasında vacib göstəricidir.

Münasibətləri idarə etmək üçün işlər aşağıda göstərilən mərhələlərlə yerinə yetirilməlidir: 
· Münasibətlər cədvəli qurulmalı və bütün münasibətlər qeyd olunmalidir;

• Münasibətlərin gücü və keyfiyyəti müəyyən edilməlidir;

- Münasibətlərin pozulmasına səbəb ola biləcək təhlükələr və zəif tərəfləri müəyyənləşdirilməlidır;

- Zamana görə münasibətlər cədvəli (münasibətlər təqvimi) qurulmalıdir;

- Qarşılıqlı münasibətlərin idarə olunması planı hazırlanmalıdır.

Münasibətlərin idarə olunmasında virtual sosial şəbəkələrin imkanlarından da geniş istifadə etmək əhəmiyyətlidir. Bunlar aşağıdakılardır:

Sosial şəbəkədə sosial qrupların yaradılması və gündəlik qrupdaxili informasiya mübadiləsi;

Sosial qrup daxilində insanların sosial problemlərinin müəyyənləşdirilməsi və həlli yollarının müzakirəsi;

Qrupun sosial kapitalından səmərəli istifadə.

İnsanların sosial-iqtisadi həyatında münasibətlər hər zaman vacib olublar, lakin son illər yaranan iki tendensiya e-dövlət mühitində münasibətlərin formasının dəyişməkdə olduğunu sübut edir: e-dövlətdə sosial media üzərindən yeni münasibətlər qurmaq və bu münasibətləri dəyişmək, konfliktlər yaradaraq münasibətləri yeni müstəviyə gətirmək asanlaşmışdır. Digər tərəfdən, e-dövlətdə kommunikasiya və qloballaşma imkanları insanların münasibətlərində dinamikliyi və şəffaflığı təmin etmişdir.

\section{NӘTIC๐}

E-dövlətdə sağlam münasibətlər vətəndaşların həyatlarında rifahın və əmin-anmanlığın təmin olunması üçün vacibdir. İnformasiya texnologiyalarının təsiri altında insanlar arasında münasibətlərin forması dəyişməkdədir. Cəmiyyətin yeni manasibətlər forması (mobil əlaqələr, sosial media vasitələri və s.) yaranmaqdadir.

Tədqiqatdan məlum oldu ki, münasibətlər zamanla dəyişən (dinamik) və ya statik olurlar. E-dövlətdə münasibətlərin zamanın tələbinə uyğun olaraq formalaşması və dəyişməsi dövlətin informasiya məkanının təhlükəsizliyi ilə sıx bağlıdır. Münasibətlərin təhlükəsizliyinin təmin olunması ilk növbədə bu münasibətlərin düzgün idarə olunması ilə əlaqədardır. Sosial şəbəkə vasitəsi ilə təsadüfi münasibətlərin yaranması, "dostların" çoxalması etimadın azalmasına və vətəndaşın nüfuzunun hər an təhlükə altında olmasına gətirir. $\mathrm{Bu}$ da cəmiyyətdə münasibətlərə ciddi təhlükədir və bu təhlükələrin qarşısını almaq üçün vətəndaşlar arasında münasibətlərin intellektual analizinə və avtomatik aşkarlanmasına ehtiyac vardır.

Minnətdarliq: Bu iş Azərbaycan Respublikasının Prezidenti yanında Elmin İnkişafı Fondunun maliyyə yardımı ilə yerinə yetirilmişdir - Qrant № EIF-BGM-4-RFTF-1/2017-21/8/1
[1]. E.Berscheid. The greening of relationship science // American Psychologist, 1999, 54(4), pp. 260-266.

[2]. O.Gillath, G.Adams, A.Kunkel. Relationship Science: Integrating Evolutionary, Neuroscience, and Sociocultural Approaches 2012, Washington, American Psychological Association, 254 p.

[3]. A.Perer, I.Guy, E.Uziel, I.Ronen, M.Jacovi. Visual social network analytics for relationship discovery in the enterprise / Proceedings of the IEEE Conference on Visual Analytics Science and Technology, 23-28 Oct. 2011, Providence, RI, USA, pp. 71-79.

[4]. https://www.relsci.com/

[5]. http://www.relatedvision.com/Traxor/traxor.html

[6]. R.I. Dunbar. How Many Friends Does One Person Need?: Dunbar's Number and Other Evolutionary Quirks, 2010, Fader and Fader limited, $302 \mathrm{p}$.

[7]. A.Smith. What people like and dislike about Facebook, 2014, http://www.pewresearch.org/fact-tank/2014/02/03/what-people-likedislike-about-facebook

[8]. M.Granovetter The Strength of Weak Ties // American Journal of Sociology, 1973, vol. 78, pp. 1360-1380.

[9]. Е.П.Ильин. Психология общения и межличностных отношений. СПб.: Питер, 2009, 576 с.

[10]. R.Collins. The Sociology of Philosophies: A Global Theory of Intellectual Change. Cambridge MA: Harvard University Press, 1998

[11]. B.Carolan. Strong Ties, Weak Ties: Relational Dimensions of Learning Settings, 2006, EdLab, Teachers College, Columbia University, 25 p. https://cdn.tc-library.org/Edlab/EdLab Strongties.pdf

[12]. K.Sanaz, I.Zuraini, Sh.Bharanidharan. Differences between Role of Strong Ties and Weak Ties in Information Diffusion on Social Network Sites // Advanced Research and Trends in New Technologies, Software, Human-Computer Interaction, and Communicability, 2014, chapter 28, pp. 307-311.

[13]. S.Wasserman, K.Faust. Social Network Analysis: Methods and Applications, 1994, Cambridge University Press, 825 p.

[14]. A.Hyvärinen, J.Karhunen, E.Oja. Independent Component Analysis. 2001, John Wiley \& Son, 476 p.

\section{SECURITTY OF SOCIAL RELATIONS İN THE E- GOVERNMENT}

\section{Rasim M. Alguliyev ${ }^{1}$, Ramiz M. Aliguliyev², Irada Y.} Alakbarova $^{3}$

Institute of Information Technology of Azerbaijan National Academy of Sciences

${ }^{1}$ r.alguliev@gmail.com, ${ }^{2}$ r.aliguliyev@gmail.com, 3 airada.09@gmail.com

\begin{abstract}
The intense and dynamic impact of information technology on everyday life and behaviour citizen has led to the creation of new relationships in society and definite changes in traditional relationships. The study analyzed the nature of the relationship between people, the relationship was classified according to form and type, and the main factors influencing the relationship were identified. Was developed proposals for the effective management of relations and solving problems of security relations in the field of e-government.

Keywords: e-government, information security, Dunbar number, actor, relationship assessment, relationship strength, relationship security.
\end{abstract}

